\title{
EXTRATO AQUOSO E FERMENTADO DE FUMO-BRAVO (Solanum mauritianum Scop) NA PROTEÇÃO DO FEIJOEIRO (Phaseolus vulgaris L.) AO CRESTAMENTO BACTERIANO COMUM
}

\author{
Fábio Junior Telaxka ${ }^{1}$, Jonas Marcelo Jaski², Daniele Carla Scheffer ${ }^{3}$, Jéssica Tais Gebauer ${ }^{4}$, Gabriela \\ Silva Moura ${ }^{5}$, Gilmar Franzener ${ }^{6}$
}

\begin{abstract}
RESUMO - O fumo-bravo (Solanum mauritianum) é uma espécie tipicamente pioneira, abundante na Floresta Estacional Decidual da Mata Atlântica. Embora lhe sejam atribuídas propriedades medicinais, pouco se sabe de seu efeito sobre doenças de plantas. Assim, esse trabalho teve por objetivo avaliar o extrato aquoso e fermentado de S. mauritianum no controle do crestamento bacteriano comum do feijoeiro, causado pela bactéria Xanthomonas axonopodis pv. phaseoli. Constituíram tratamentos o extrato aquoso nas concentrações de 0,$1 ; 5 ; 10,15$ e $20 \%$, bem como os fermentados de fumo-bravo com e sem a adição de açúcar mascavo a $3 \%$ com 5,10 , 15 e 20 dias de fermentação. Foram realizados ensaios de atividade antimicrobiana in vitro sobre a bactéria, indução da fitoalexina faseolina em hipocótilos de feijoeiro. Em plantas de feijoeiro, em casa de vegetação, foi avaliada a severidade da doença em trifólios tratados e em não tratados. Também foram coletadas amostras foliares 72 horas após os tratamentos para determinação da atividade de polifenoloxidase (POX) e fenilalanina amônia-liase (FAL). Os ensaios foram conduzidos em delineamento inteiramente casualizado com quatro repetições. $\mathrm{O}$ extrato aquoso induz a síntese de faseolina e os fermentados reduzem significativamente o crescimento de $X$. axonopodis pv. phaseoli. O extrato aquoso e o fermentado reduzem a severidade do crestamento bacteriano em folhas tratadas. O extrato aquoso e o fermentado reduzem a severidade do crestamento bacteriano em folhas tratadas e induzem a atividade das enzimas POX e FAL. Os resultados indicam o potencial de derivados de fumo-bravo na proteção de plantas de feijoeiro ao crestamento bacteriano comum.
\end{abstract}

Palavras chave: controle alternativo, fenialanina amônia-liase, fitoalexinas, polifenoloxidase, Xanthomonas axonopodis pv. phaseoli.

\section{AQUEOUS AND FERMENTED EXTRACT OF Solanum mauritianum SCop FOR Phaseolus vulgaris L. PROTECTION TO THE COMMON BACTERIAL BLIGHT}

\begin{abstract}
The Solanum mauritianum is a typically pioneer species, abundant in the Decidual Seasonal Forest of the Atlantic Forest. Although medicinal properties are attributed to it, little is known of its effect on plant diseases. Thus, the objective of this work was to evaluate the aqueous and fermented extract of $S$. mauritianum in the control of the common bacterial blight of common bean, caused by the bacterium Xanthomonas axonopodis pv. phaseoli. The aqueous extract was treated at concentrations of 0.1, 5; 10, 15 and 20\%, as well as the wild-type fermented with and without the addition of 3\% brown sugar with 5, 10, 15 and 20 days of fermentation. In vitro antimicrobial activity tests were carried out on the bacterium, induction of phytoalexin phaseolin in bean hypocotyls. In common bean plants, the severity of the disease was evaluated in treated
\end{abstract}

\footnotetext{
${ }^{1}$ Mestre em Agronomia, Universidade Estadual do Centro-Oeste, UNICENTRO, Guarapuava-PR.

${ }^{2}$ Doutorando em Agronomia, Universidade Estadual de Maringá, UEM, Maringá-PR.

${ }^{3}$ Graduanda em Agronomia, Universidade Federal da Fronteira Sul - UFFS, Campus Laranjeiras do Sul - PR.

${ }^{4}$ Mestranda em Agroecologia e Desenvolvimento Rural Sustentável, Universidade Federal da Fronteira Sul - UFFS, Campus Laranjeiras do Sul - PR.

${ }^{5}$ Pós-Doutoranda no Programa de Pós-Graduação em Agroecologia e Desenvolvimento Rural Sustentável (PNPD/Capes), Universidade Federal da Fronteira Sul - UFFS, Campus Laranjeiras do Sul - PR.

${ }^{6}$ Docente, Universidade Federal da Fronteira Sul - UFFS, Campus Laranjeiras do Sul - PR, gilmar.franzener@uffs.edu.br.
} 
and untreated trifolia. Leaf samples were collected 72 hours after the treatments to determine the polyphenoloxidase (POX) and phenylalanine ammonia-lyase activity (FAL). The trials were conducted in a completely randomized design with four replicates. The aqueous extract induces phaseolin synthesis and the fermented ones significantly reduce the growth of $X$. axonopodis pv. phaseoli. Aqueous and fermented extract reduce the severity of bacterial blight on treated leaves. The aqueous and fermented extract reduce the severity of bacterial blight on treated leaves and induce the activity of POX and FAL enzymes. The results indicate the potential of wild smoke derivatives in the protection of common bean plants to common bacterial blight.

Keywords: alternative control, phenylalanine ammonia-lyase, phytoalexins, polyphenoloxidase, Xanthomonas axonopodis pv. phaseoli.

\section{INTRODUÇÃO}

A cultura do feijoeiro (Phaseolus vulgaris L.) pode ter sua produção comumente afetada por diversas doenças (Bianchini et al., 2005). Dentre os problemas fitossanitários do feijoeiro, o crestamento bacteriano comum, causado pela bactéria Xanthomonas axonopodis pv. phaseoli, representa a principal doença bacteriana da cultura no Brasil. É uma bacteriose que pode provocar redução de 10 a 70\% na produção (Diaz, 2000). De acordo com Vigo et al. (2009), está é uma doença de difícil controle, de ocorrência comum e que pode ser transmitida por sementes. Além disso, há escassez de produtos que podem ser utilizados com eficiência no controle da doença.

A busca por métodos mais sustentáveis para proteção de plantas e de menor impacto ao ambiente e à saúde humana, tem levado ao desenvolvimento de pesquisas com intuito de obter produtos naturais eficientes no controle de doenças de plantas (Dayan et al., 2009). Dentre esses produtos naturais, tem merecido destaque os derivados de plantas, como os extratos e óleos essenciais (Kuhn et al., 2006). Esses derivados podem atuar na proteção de plantas a doenças por diversos mecanismos, incluindo a ação antimicrobiana direta sobre o fitopatógeno (Didwania et al., 2013; Kotan et al., 2013) ou a ativação de mecanismos de defesa nas plantas (Franzener et al., 2018). A ação tanto antimicrobiana como indutora de mecanismos de defesa em plantas por derivados vegetais deve-se a presença de compostos ativos nessas espécies, geralmente originários do metabolismo secundário. Entre os mecanismos de defesa da planta que podem ser ativados por derivados vegetais estão as fitoalexinas (Moura et al., 2014), que são compostos antimicrobianos de baixo peso molecular sintetizados pela planta (Ahuja et al., 2012). Entre outras respostas bioquímicas que podem ser ativadas nas plantas em resposta ao tratamento com agentes bióticos ou abióticos estão as enzimas relacionadas a defesa vegetal, como as polifenoloxidases e a fenilalanina amônia-liase (Barros et al., 2010).

Também outros derivados de plantas medicinais, como os hidrolatos, já tem demonstrado potencial no controle de doenças, tanto por ação direta sobre os fitopatógenos como induzindo mecanismos de defesa em plantas (Moura et al., 2014). No entanto, sobre alguns derivados, como os fermentados vegetais, ainda há poucos estudos. Há relatos de que a fermentação pode aumentar a atividade biológica de plantas medicinais (Hussain et al., 2016) O desenvolvimento de produtos naturais que auxiliem no controle de doenças bacterianas assumem ainda maior importância devido a escassez de produtos e as dificuldades de controle.

O fumo-bravo (Solanum mauritianum) é uma planta pioneira e robusta, pertencente a família das Solanaceas, com ocorrência bastante comum na Mata Atlântica, na Floresta Ombrófila Mista e Densa e na Floresta Estacional Decidual e Semidecidual (Barroso, 1991). Embora seja uma espécie vegetal muito comum e conhecida, as pesquisas e resultados de aplicações práticas referentes ao uso de derivados dessa planta na agricultura ainda estão escassos. Contudo, alguns trabalhos publicados relatam a efetividade na utilização desses materias, tais como Mdee et al. (2009) que verificaram que o extrato de folhas e frutos de $S$. mauritianum, assim como o de outras espécies, apresentam efeito inibitório sobre alguns fungos fitopatogênicos, e De León et al. (2013) que trabalhando com extrato fermentado de Flourensia cernua também constaram que o fermentado apresenta atividade inibitória sobre Penicillium expansum and Fusarium oxysporum (De León et al., 2013).

Diante disso, esse trabalho teve como objetivo avaliar o uso de extrato aquoso e fermentados de fumobravo na proteção de plantas de feijoeiro ao crestamento 
bacteriano comum, avaliando tanto o efeito sobre o fitopatógeno como na ativação de mecanismos relacionados a defesa vegetal.

\section{MATERIAL E MÉTODOS}

O trabalho foi desenvolvido no Laboratório de Fitopatologia e em casa de vegetação climatizada na Universidade Federal da Fronteira Sul, Campus Laranjeiras do Sul - PR.

\section{Obtenção do fermentado e extrato aquoso de fumo-bravo}

Para obtenção dos preparados, folhas frescas de fumo-bravo foram coletadas de plantas de ocorrência espontânea no município de Laranjeiras do Sul/PR, no período da manhã, em agosto de 2015. O extrato aquoso a $20 \%$ foi obtido através da trituração de $100 \mathrm{~g}$ de folhas frescas de fumo-bravo em liquidificador contendo $500 \mathrm{~mL}$ de água destilada por 30 segundos. Em seguida o material foi filtrado em gaze e em papel de filtro. Para obtenção de diferentes concentrações o extrato foi diluído em água destilada.

Para obtenção dos fermentados, as folhas frescas foram pesadas e cortadas em fragmentos homogêneos de aproximadamente $0,5 \mathrm{~cm}$ na proporção de 100 gramas de folha para cada $1000 \mathrm{~mL}$ de água destilada. Em seguida o material foi acondicionado em garrafas pet, capacidade de $2 \mathrm{~L}$, por $5,10,15$ e 20 dias no escuro a $25^{\circ} \mathrm{C}$, com ou sem a adição de açúcar mascavo a $3 \%$. Após o período de fermentação, o material foi filtrado em gaze e papel de filtro.

\section{Isolamento, manutenção e preparo do inóculo do fitopatógeno}

O isolado da fitobactéria $X$. axonopodis pv. phaseoli foi obtido a partir de folhas sintomáticas de feijoeiro na região de Laranjeiras do Sul-PR. Esta foi cultivada em placas de Petri contendo meio de cultura ágar nutriente ( 5 g peptona; $3 \mathrm{~g}$ extrato de carne; $15 \mathrm{~g}$ ágar bacteriológico e $1000 \mathrm{~mL}$ de água destilada) e mantidas a $28^{\circ} \mathrm{C} \mathrm{em}$ escuro por 48 horas para o preparo do inóculo. A suspensão bacteriana foi preparada em solução salina ( $\mathrm{NaCl}$ 0,85\%) com concentração ajustada para $1 \times 10^{8}$ UFC $\mathrm{mL}^{-1}$, com base em curva de absorbância a 580 $\mathrm{nm}$ (Kuhn, 2006). A manutenção da bactéria por períodos prolongados foi realizada através de inoculação e reisolamento em plantas de feijoeiro.

\section{Ensaio de atividade antimicrobiana}

Para avaliação da atividade direta dos fermentados e dos extratos aquosos sobre X. axonopodis pv. phaseoli, foi conduzido experimento em tubos de ensaio (capacidade $10 \mathrm{~mL}$ ) para o qual cada tubo recebeu concentrações iguais do meio caldo nutriente e os respectivos tratamentos, totalizando o volume final de $5 \mathrm{~mL}$ por tubo. Em seguida os tubos de ensaio, contendo os tratamentos, foram autoclavados a 120 ${ }^{\circ} \mathrm{C}$ por $20 \mathrm{~min}$. Após os tubos atingirem temperatura ambiente foi adicionado a cada tubo $100 \mathrm{iL}$ de suspensão bacteriana com $1 \times 10^{8}$ UFC (unidades formadoras de colônia) $\mathrm{mL}^{-1}$. Os tubos foram mantidos por 48 horas a $27^{\circ} \mathrm{C}$ em escuro e após determinada a absorbância a $580 \mathrm{~nm}$.

Foram avaliados os biofermentados (a 10\%) com ou sem açúcar mascavo de $5,10,15$ e 20 dias de fermentação, além de extrato aquoso a $0,1,5,10,15$ e $20 \%$.

\section{Ensaio de indução de fitoalexina}

A determinação da fitoalexina faseolina foi realizada com base na metodologia de Dixon et al. (1983), com algumas modificações. Sementes de feijoeiro da variedade Tuiuiu foram desinfestadas em solução de hipoclorito de sódio $0,5 \%$ por 3 minutos. Em seguida foram lavadas em água destilada estéril, semeadas em areia esterilizada por autoclavagem $\left(120^{\circ} \mathrm{C}\right.$ por uma hora a $\left.1 \mathrm{~atm}\right)$ e mantidas em escuro a $24^{\circ} \mathrm{C}$ durante nove dias. Após esse período, segmentos de hipocótilos estiolados com $5 \mathrm{~cm}$ foram destacados das plântulas, lavados em água estéril e mantidos sobre papel absorvente por 30 minutos. Quatro segmentos de hipocótilo (com aproximadamente $1 \mathrm{~g}$ ) foram colocados em cada placa de Petri contendo papel de germinação umedecido com água destilada estéril. Em seguida os tratamentos foram pulverizados sobre os hipocótilos até ponto de escorrimento. As placas de Petri foram tampadas e mantidas a $24^{\circ} \mathrm{C}$ em escuro por $48 \mathrm{~h}$. Após esse período, os hipocótilos foram transferidos para tubos de ensaio contendo $10 \mathrm{~mL}$ de etanol $70 \%$, mantidos a $4{ }^{\circ} \mathrm{C}$ por $48 \mathrm{~h}$, e agitados por uma hora para extração da fitoalexina. $\mathrm{O}$ teor de faseolina foi mensurado indiretamente através do espectrofotômetro a $280 \mathrm{~nm}$.

Em um primeiro bioensaio foi avaliado o extrato aquoso nas concentrações de $0,1,5,10,15$ e $20 \%$. Em outro bioensaio foram avaliados os fermentados 
na concentração de $10 \%$, com 0 (sem fermentação) 5 , 10,15 e 20 dias de fermentação, com ou sem adição de açúcar mascavo (3\%).

\section{Efeito protetor em plantas de feijoeiro}

Para avaliar o efeito protetor do extrato aquoso e fermentados sobre o crestamento bacteriano comum, plantas de feijoeiro variedade Tuiuiu foram cultivadas em vasos plásticos (capacidade de 2 litros) contendo mistura de solo, areia e composto orgânico na proporção de 2:1:1, respectivamente. Em cada vaso foram semeadas cinco sementes, sendo realizado desbaste 15 dias após a semeadura. As plantas foram mantidas em casa de vegetação e irrigadas diariamente, sob temperatura de $25 \pm 2{ }^{\circ} \mathrm{C}$ e umidade relativa de aproximadamente $70 \%$.

Aos 60 dias após a semeadura, os tratamentos foram aplicados via aspersão no primeiro trifólio de cada planta. Três dias após, foi realizada a inoculação com suspensão bacteriana de $1 \times 10^{8} \mathrm{UFC} \mathrm{mL}^{-1}$ no primeiro (tratado) e no segundo trifólio (não tratado). A inoculação foi realizada por meio de aspersão com o inóculo, sendo estas mantidas em câmara úmida por 6 horas antes e 24 horas depois da inoculação, com umidade relativa de $100 \%$.

Para a determinação da severidade do crestamento bacteriano comum no feijoeiro foi utilizada a escala diagramática adaptada por Azevedo (1997), sendo o resultado expresso em porcentagem de área foliar lesionada. Constituíram tratamentos fermentados com 15 dias com e sem a adição de açúcar mascavo, extrato aquoso a $10 \%$, com e sem a adição de açúcar mascavo, além da testemunha água destilada.

\section{Avaliação de enzimas relacionadas à defesa em plantas de feijoeiro}

Experimento nos moldes do anterior foi conduzido para avaliar o potencial efeito indutor de enzimas relacionadas a defesa nas plantas de feijoeiro pelos tratamentos. Nesse caso, os tratamento foram aplicados quando as plantas atingiram o estádio V3/V4, com 30 dias após a semeadura. Os tratamentos utilizados foram os fermentados com 5, 10, 15 e 20 dias de fermentação sem e com adição de açúcar mascavo, extrato aquoso a $0,1,5,10$ e $15 \%$. Os tratamentos foram pulverizados no primeiro trifólio das plantas até o ponto de escorrimento.
Três dias após a aplicação dos tratamentos foram coletados discos foliares com $1,5 \mathrm{~cm}$ de diâmetro, sendo 5 discos do primeiro trifólio (tratado) e cinco discos do segundo trifólio (não tratado) de cada parcela. Os discos foliares foram acondicionados em papel alumínio e imediatamente transferidos para freezer e mantidos a $-20^{\circ} \mathrm{C}$ até a realização das análises bioquímicas.

As amostras de tecido foliar foram maceradas em $4 \mathrm{~mL}$ de tampão fosfato $0,01 \mathrm{M}(\mathrm{pH} 6,0)$ contendo $1 \%$ $(\mathrm{p} / \mathrm{p})$ de PVP (Polivinilpirrolidona), em almofariz de porcelana. Os homogeneizados foram centrifugados a $14.500 \mathrm{~g}$ durante $20 \mathrm{~min}$ a $4{ }^{\circ} \mathrm{C}$. O sobrenadante obtido, considerado como extrato enzimático, foi utilizado para a determinação do conteúdo de proteínas e atividade enzimática. Todo o material empregado foi mantido sob refrigeração.

A atividade das polifenoloxidases foi determinada conforme a metodologia proposta por Duangmal e Apenten (1999). Para tanto, o substrato para enzima foi composto por catecol, na concentração de $20 \mathrm{mM}$, dissolvido em tampão fosfato de potássio $100 \mathrm{mM}(\mathrm{pH}$ 6,8). A reação foi conduzida misturando-se 900 iL do substrato e $100 \mathrm{iL}$ do extrato enzimático seguida de leituras em espectrofotômetro, a $420 \mathrm{~nm}$. As leituras foram realizadas de forma direta por um período de $2 \mathrm{~min}$. Os resultados foram expressos em variação min ${ }^{1}$ g.p.f. ${ }^{-1}$ (grama de peso fresco).

A atividade de fenilalanina amônia-liase foi determinada de acordo com a metodologia descrita por Umesha (2006), na qual $100 \mu \mathrm{L}$ do extrato enzimático foram acrescidos de $400 \mu \mathrm{L}$ de tampão Tris- $\mathrm{HCl}$ 0,025 $\mathrm{M}(\mathrm{pH} 8,8)$ e $500 \mu \mathrm{L}$ de solução de L-fenilalanina 0,05 M(825,9 mg diluído em $100 \mathrm{~mL}$ de tampão Tris-HCL 0,025 $\mathrm{M}(\mathrm{pH} 8,8)$ ). Incubou-se essa mistura a $40{ }^{\circ} \mathrm{C}$ durante $2 \mathrm{~h}$. Ao final desse período adicionaram-se $60 \mu \mathrm{L} \mathrm{de} \mathrm{HCl}$ $5 \mathrm{M}$ para cessar a reação, seguindo-se a leitura em espectrofotômetro a $290 \mathrm{~nm}$. A atividade de fenilalanina amônia-liase consistiu da diferença entre a absorbância da mistura contendo amostra e do controle $(100 \mu \mathrm{L}$ de extrato enzimático e $900 \mu \mathrm{L}$ de tampão Tris- $\mathrm{HCl} 0,025 \mathrm{M}$ (pH 8,8)), a qual foi plotada em curva padrão para ácido trans-cinâmico. Os resultados foram expressos em microg de ácido trans-cinâmico ${ }^{-1}$ g.p.f. ${ }^{-1}$ (gramas de peso fresco).

\section{Análise dos resultados}

Os resultados foram submetidos a análise de variância e teste de Tukey a 5\% de probabilidade para 
dados qualitativos e análise de regressão para os diferentes tempos e concentrações utilizadas. As análises foram realizadas com auxílio do sistema computacional ASSISTAT versão 7.7. (Silva \& Azevedo, 2002).

\section{RESULTADOS E DISCUSSÃO}

Atividade antibacteriana sobre $X$. axonopodis pv. phaseoli

O extrato aquoso de $S$. mauritianum apresentou efeito quadrático sobre a bactéria $X$. axonopodis pv. phaseoli (Figura 1A). Pela equação de regressão, o ponto de máxima foi observado na concentração de $15,7 \%$, indicando que houve incremento no desenvolvimento da bactéria em relação às menores concentrações. O extrato aquoso de plantas podem
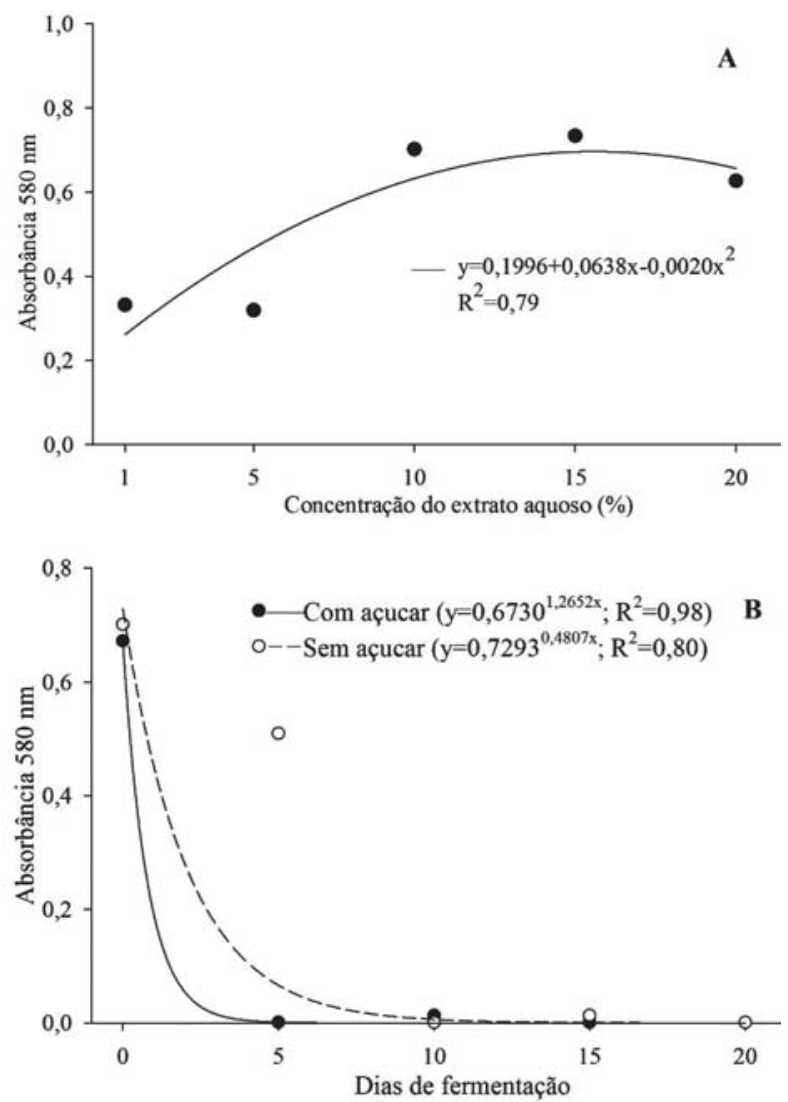

Figura 1 - Desenvolvimento de Xanthomonas axonopodis pv. phaseoli sob diferentes concentrações do extrato aquoso (A) e de biofermentados de fumo-bravo a $10 \%$ com e sem a adição de açúcar mascavo (B). apresentar grande diversidade de compostos e com diferentes atividades biológicas, incluindo antimicrobianos, antioxidantes e mesmo estimulantes. Assim, é possível que o resultado das concentrações e interações entre esses compostos contribua para que o derivado vegetal possa apresentar maior ou menor efeito em diferentes concentrações.

No caso do uso dos fermentados de fumo-bravo os resultados foram mais expressivos, havendo inibição total do desenvolvimento microbiano a partir de cinco dias de fermentação quando incorporado açúcar mascavo a 3\%, e a partir de 10 dias quando não houve a incorporação de açúcar (Figura 1B). Esse resultado demonstra o potencial da fermentação do extrato de fumo-bravo para potencializar o efeito inibitório sobre a bactéria. A incorporação do açúcar mascavo a 3\% possivelmente acelerou o processo fermentativo, permitindo maior efeito antimicrobiano após 5 dias de fermentação. Incremento em propriedades farmacológicas e terapêuticas de plantas medicinais pela fermentação também já tem sido relatadas na literatura (Hussain et al., 2016).

Embora o potencial de extratos e óleos essenciais de plantas, principalmente medicinais, tem sido estudados nos últimos anos no controle fitossanitário (Kotan et al., 2013; Franzener et al., 2018), ainda são poucas as informações sobre o uso de fermentados vegetais. Como exemplo, Mdee et al. (2009) verificaram que extrato de algumas espécies vegetais de ocorrência espontânea, incluindo $S$. mauritianum, promoveram efeito inibitório sobre alguns fungos fitopatogênicos. Também De León et al. (2013) verificaram que o fermentado do extrato aquoso de Flourensia cernua apresentou atividade inibitória sobre os fungos Penicillium expansum e Fusarium oxysporum.

O efeito antimicrobiano de um produto natural representa um importante indicador de seu potencial no controle de determinada doença. No entanto, há situações em que mesmo sem ação antimicrobiana direta sobre o fitopatógeno pode haver controle da doença, possivelmente pela ativação de mecanismos de defesa vegetal (Silva et al., 2008). Também o fato de ser observada ação antimicrobiana in vitro pode não pode ser traduzido em controle efetivo da doença a campo (Kuhn et al., 2006), possivelmente pelos diversos fatores envolvidos nas condições in vivo. 


\section{Indução de faseolina em feijoeiro}

O extrato aquoso de fumo-bravo promoveu incremento de faseolina em hipocótilos de feijoeiro com o aumento na concentração utilizadas (Figura 2A). Esse resultado mostra o potencial em induzir essa fitoalexina pelo extrato de fumo-bravo.

Não foram encontrados trabalhos na literatura com a utilização de extrato de fumo-bravo na indução de faseolina em feijoeiro. No entanto, há trabalhos com a utilização de extratos de outras plantas, ou mesmo com outros tipos de indutores, os quais demonstram resultados positivos sobre a indução de faseolina no feijoeiro. Brand et al. (2010) avaliaram o efeito de extratos aquosos autoclavados e não autoclavados de alecrim sobre a produção de faseolina no feijoeiro, e notaram que os extratos não autoclavados são mais efetivos na sua indução.

Quanto ao tempo de fermentação não foi observada diferença significativa no acúmulo de faseolina, tanto com ou sem a incorporação de açúcar mascavo nos fermentados de fumo-bravo a 10\% (Figura 2B).

As fitoalexinas são compostos antimicrobianos produzidos pela planta como um importante mecanismo bioquímico de defesa. As mais estudadas são as deoxiantocianidinas em sorgo e a gliceolina em soja (Ahuja et al., 2012; Moura et al., 2014), comumente relacionadas com a redução na severidade de doenças em plantas.

\section{Efeito protetor em plantas de feijoeiro}

A severidade do crestamento bacteriano nas plantas de feijoeiro foi reduzida com a aplicação dos tratamentos em relação a testemunha tratada apenas com água destilada, a qual apresentou $10,6 \%$ de área foliar lesionada (Tabela 1). No entanto, a diferença entre os tratamentos foi observada somente nos trifólios tratados (primeiro trifólio).

Os tratamentos que propiciaram menor severidade da doença foram o extrato aquoso a $10 \%$, com e sem adução de açúcar mascavo, e o fermentado de fumobravo com 15 dias de fermentação com açúcar mascavo a $3 \%$. O fermentado sem açúcar apresentou valores intermediários de severidade, não diferindo da testemunha água e do fermentado com açúcar. Os resultados demonstram efeito protetor ao crestamento bacteriano em plantas de feijoeiro tanto pelo extrato aquoso como pelo fermentado.
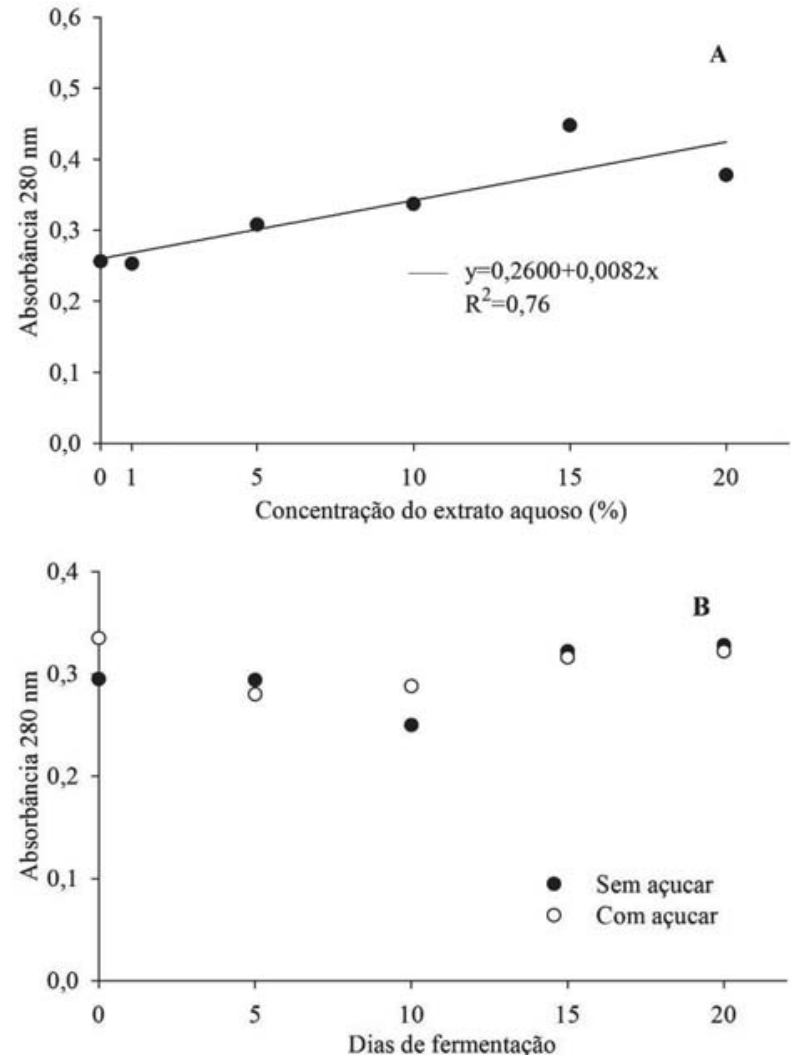

Figura 2 - Teor de faseolina em hipocótilos de feijoeiro tratados com diferentes concentrações do extrato aquoso (A) e de fermentados a $10 \%$ (B) de fumo-bravo com ou sem adição de açúcar.

Nos segundos trifólios das plantas, que não receberam os tratamentos, não foi observada diferença significativa entre os tratamentos e a testemunha. No entanto, um dos resultados de maior destaque é o valor significativamente menor da severidade da doença na testemunha água no trifólio não tratado em relação ao trifólio tratado com água. Possivelmente o fato de ter ocorrido menor severidade da doença em trifólios não tratados em relação aos tratados com água destilada não se refere a efeito sistêmico mas sim a fatores intrínsecos da própria planta. Possivelmente contribua para isso o fato de o segundo trifólio (não tratado) ser mais jovem que o primeiro trifólio, podendo apresentar composição distinta, como maior compostos antimicrobianos, por exemplo.

Ainda pouco se sabe sobre o efeito de derivados de fumo-bravo na proteção de plantas. Devido a 
Tabela 1 - Médias da severidade do crestamento bacteriano comum do feijoeiro (X. axonopodis pv. phaseoli)

\begin{tabular}{lcc}
\hline Tratamentos & Severidade (\%) \\
\hline & $1^{\circ}$ trifólio & $2^{\circ}$ trifolio \\
Água destilada & $10,6 \mathrm{aA}$ & $1,8 \mathrm{aB}$ \\
EA $10 \%$ sem açúcar & $2,6 \mathrm{bcA}$ & $2 \mathrm{aA}$ \\
Fermentado sem açúcar por 15 dias & $6,6 \mathrm{abA}$ & $2 \mathrm{aB}$ \\
EA 10\% com açúcar & $1 \mathrm{cA}$ & $0,4 \mathrm{aA}$ \\
Fermentado com açúcar por 15 dias & $3 \mathrm{bcA}$ & $1,2 \mathrm{aA}$ \\
\hline
\end{tabular}

Médias seguidas de mesma letra minúscula na coluna e maiúscula na linha não diferem entre si pelo teste de Tukey ao nível de 5\% de probabilidade.

importância do crestamento bacteriano comum no feijoeiro, outras alternativas já foram avaliadas e demonstraram efeitos promissores. Um exemplo é o trabalho desenvolvido por Silva et al. (2008) em que observaram o controle biológico de $X$. axonopodis pv. phaseoli por um isolado de Pseudomonas. Nesse trabalho os autores verificaram o controle da doença mesmo sem haver a inibição direta do fitopatógeno, sugerindo, nesse caso, o envolvimento de indução de resistência. Esse efeito possivelmente ajuda a explicar o fato de o extrato aquoso de $S$. mauritianum não ter promovido efeito inibitório sobre $X$. axonopodis pv. phaseoli mas ter reduzido a severidade da doença.

Redução da severidade do crestamento bacteriano comum em até $47 \%$ foi encontrada por Viecelli e Moerschbächer (2013) quando aplicado manganês via foliar no feijoeiro no estágio V2 e comparando com as testemunhas água, bactericida Agrimicina (50 mg i.a. $\mathrm{L}^{-1}$ ) e acibenzolar-S-metil (75 mg i.a. $\left.\mathrm{L}^{-1}\right)$. Diaz et al. (2000) também relataram que a severidade da doença não apresenta relação linear significativa com a produção, no entanto, observaram que a duração da área foliar sadia relacionou-se linearmente de forma significativa (Pd'0,01) com a produção em duas diferentes variedades. Redução na severidade do crestamento bacteriano comum em feijoeiro também foi observado por Vigo et al. (2009) avaliando óleos essenciais e tinturas de outras espécies vegetais, também sugerindo o envolvimento de mecanismos de defesa vegetal ativados em função dos tratamentos.

\section{Atividade da polifenoloxidases e fenilalanina amônia-liase}

O fermentado de fumo-bravo sem açúcar não proporcionou aumento da atividade da enzima polifenoloxidases (Figura 3A). O tratamento promoveu redução na atividade da enzima no primeiro trifólio do feijoeiro nos tempos intermediários de fermentação, sendo demonstrado pela equação quadrática. No segundo trifólio não houve diferença entre os dias de fermentação do preparado para atividade dessa enzima.

Quando utilizado o biofermentado de fumo-bravo com açúcar foi observado efeito quadrático tanto em trifólios tratados como não tratados, havendo redução na atividade em tempos de fermentação intermediários e aumento na atividade dessa enzima nos maiores tempos de fermentação. O fermentado com 20 dias de fermentação em folhas tratadas promoveu incremento de até $276 \%$ na atividade da enzima em relação ao tratamento sem fermentação (0). Já em trifólios não tratados não houve aumento na atividade de polifenoloxidases em relação ao tratamento sem fermentação (Figura 3 B).

Com a aplicação do extrato aquoso sobre as folhas do feijoeiro e analise após 72 horas, houve efeito indutor na atividade da polifenoloxidases em trifólios tratados (Figura $3 \mathrm{C}$ ).

Esses resultados evidenciam que tanto o extrato aquoso como o fermentado possuem compostos indutores da síntese dessa enzima em folhas de feijoeiro. No entanto, essa atividade indutora se restringe ao efeito local, não apresentando efeito sistêmico em folhas não tratadas. As polifenoloxidases envolvem a degradação oxidativa de compostos fenólicos levando a polimerização de quinonas (Barros et al., 2010), assim a sua indução torna-se importante para defesa vegetal. Em feijoeiro essa enzima também já foi associada a redução na severidade da antracnose causada pelo fungo Colletotrichum lindemuthianum (Campos et al., 2004) bem como do crestamento bacteriano comum (Vigo et al., 2009).

Quanto a atividade da enzima fenilalanina amônialiase, os fermentados de fumo-bravo, tanto sem (Figura 
4A) como com (Figura 4B) a adição de açúcar mascavo promoveram alterações na atividade dessa enzima. Os fermentados com maior tempo de fermentação (20 dias) promoveram maior atividade de fenilalanina amônialiase em folhas tratadas. Já no segundo trifólio (não tratado) houve efeito quadrático com indução dessa
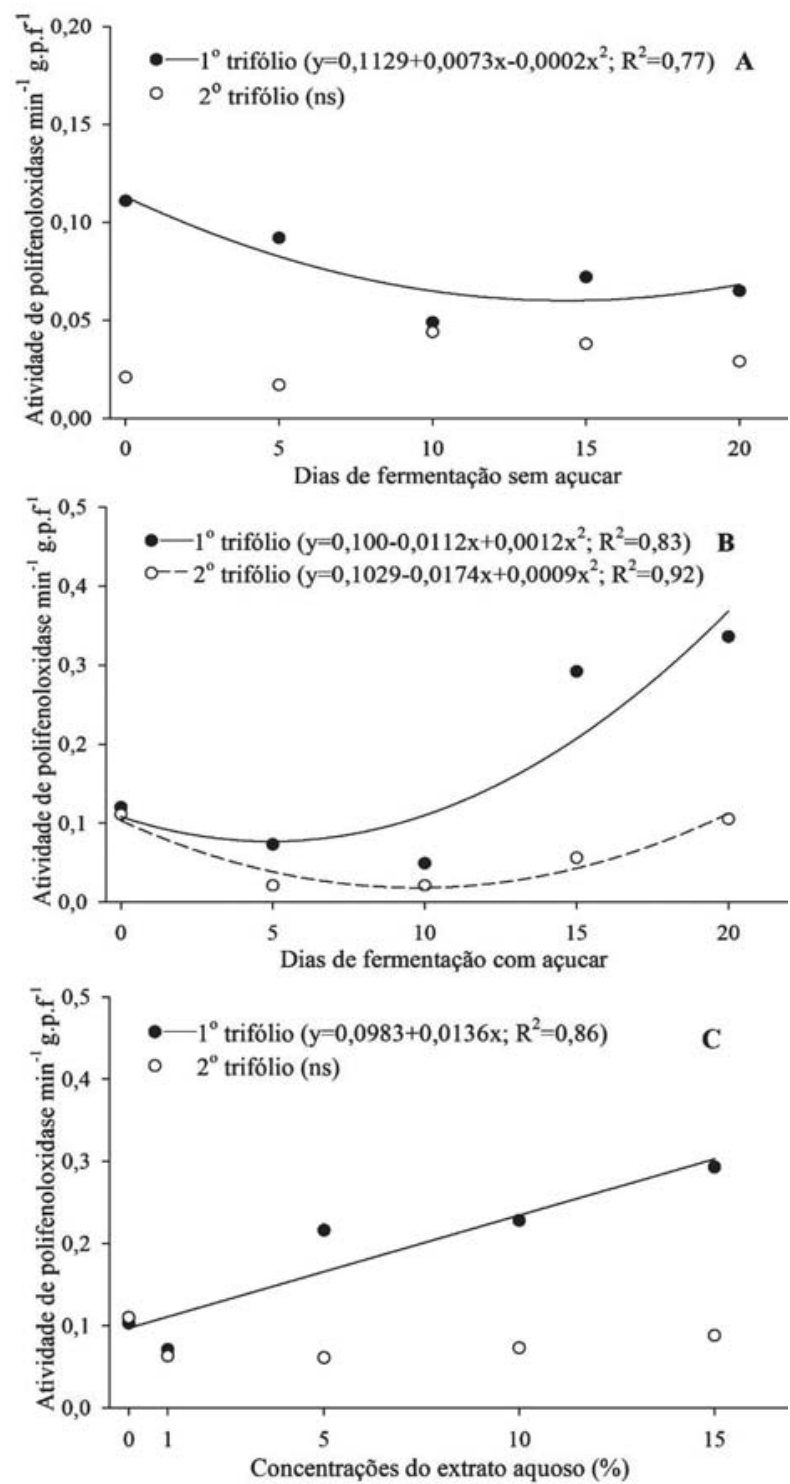

Figura 3 - Atividade da polifenoloxidase com a utilização de fermentados sem (A) e com (B) adição de açúcar mascavo, ou uso de extrato aquoso (C) de fumo-bravo após 72 horas na $1^{\mathrm{a}}$ e $2^{\mathrm{a}}$ folha trifoliada. ns: não significativo. enzima em tempos intermediários de fermentação, tanto com como sem a adição de açúcar (3\%).

Quando foram utilizadas diferentes concentrações do extrato aquoso de fumo-bravo houve aumento linear significativo na atividade de fenilalanina amônia-liase com o aumento na concentração do extrato em trifólios
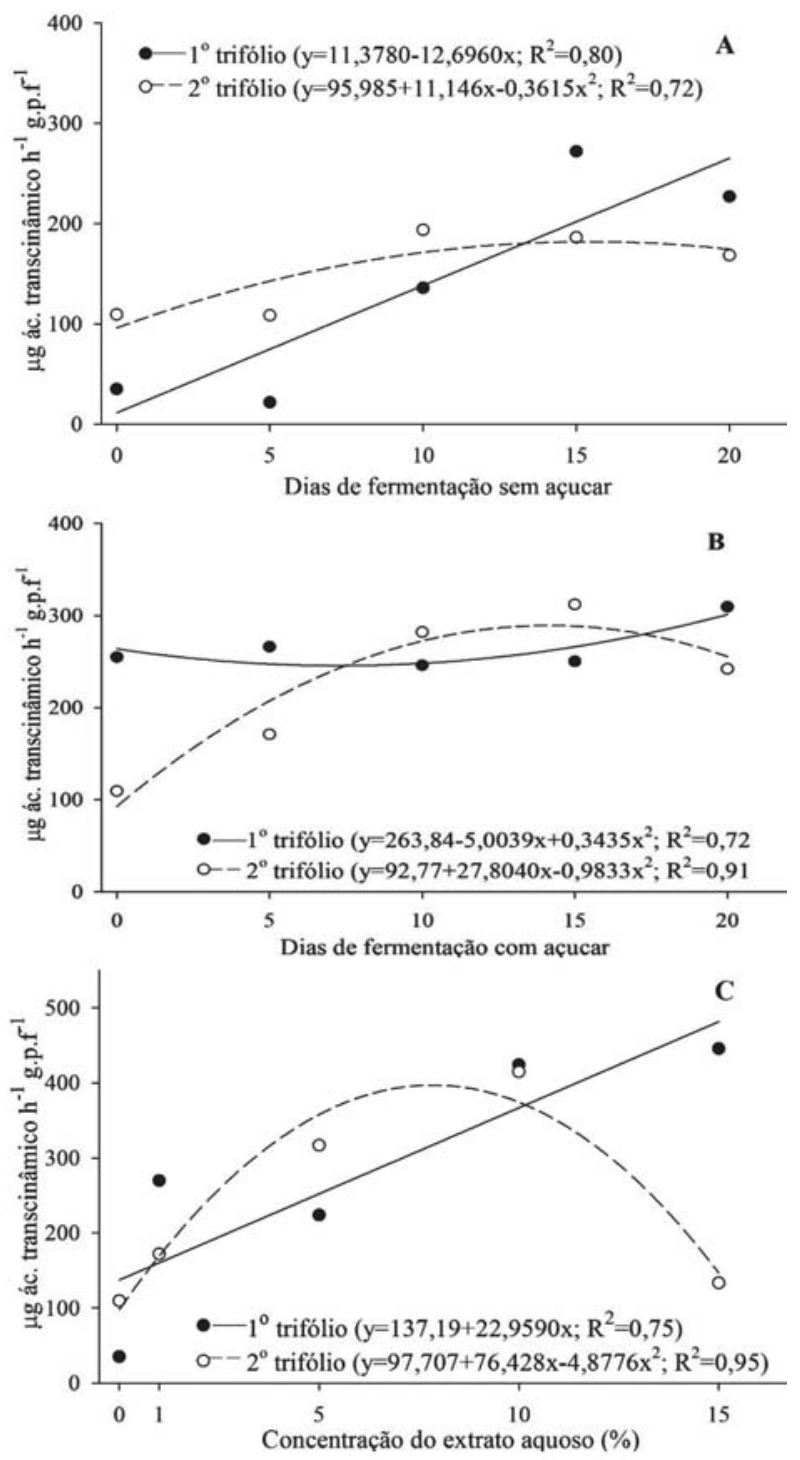

Figura 4 - Atividade da fenialanina amônia-liase com a utilização de fermentados sem (A) e com (B) adição de açúcar mascavo, ou diferentes concentrações do extrato aquoso (C) após 72 horas na $1^{\mathrm{a}}$ e $2^{\mathrm{a}}$ folha trifoliada. 
que receberam os tratamentos (Figura 4C). Já em trifólios não tratados também houve incremento na atividade dessa enzima mas em concentrações intermediárias, tendo ponto de máxima na concentração de $7,8 \%$ do extrato. Os resultados obtidos demonstram que tanto o fermentado como o extrato aquoso possuem compostos com efeito indutor dessa enzima, tanto em folhas tratadas como em folhas não tratadas, indicando potencial efeito sistêmico. No entanto, efeito indutor em folhas não tratadas foram observados somente em concentrações ou tempos de fermentação intermediárias, para o extrato aquoso e fermentados, respectivamente.

Os resultados obtidos com aumento na atividade da fenilalanina amônia-liase são importantes indicadores do potencial efeito indutor de resistência em plantas de feijoeiro pelo extrato e fermentado de fumo-bravo, uma vez que essa enzima possui uma papel muito importante na ramificação do metabolismo primário para formação de metabólitos secundários em plantas. Alguns trabalhos já tem relacionado o aumento na atividade da fenilalanina amônia-liase com a redução na severidade de doenças. Ao trabalhar com arroz induzido com Pseudomonas fluorenscens contra Xanthomonas oryzae pv. oryza, Vidhyasekaram et al. (2001) observaram redução na severidade da mancha bacteriana em $85 \%$ associado ao aumento da atividade da fenilalanina amônia-liase. O potencial efeito indutor de polifenoloxidases e fenilalanina amônia-liase já foi relatado em diferentes culturas por derivados vegetais de outras espécies (Vigo et al., 2009; Franzener et al., 2018).

Considerando a importância das polifenoloxidases e de fenilalanina amônia-liase na defesa vegetal e a indução das mesmas pelo extrato aquoso e fermentado de fumo-bravo, os resultados sugerem que a proteção de plantas de feijoeiro ao crestamento bacteriano comum por esses derivados vegetais envolve também a indução de resistência nas plantas.

\section{CONCLUSÕES}

O extrato aquoso de fumo-bravo induz a síntese de faseolina em hipocótilos de feijoeiro, conforme aumento na concentração do extrato. Já os fermentados não induzem faseolina independentemente da forma e tempo de preparo.

Os fermentados apresentam efeito antibacteriano sobre $X$. axonopodis pv. phaseoli, o que já não ocorreu com uso do extrato aquoso. Os fermentados e o extrato aquoso reduzem a severidade do crestamento bacteriano em folhas de feijoeiro bem como promovem incremento na atividade de polifenoloxidases (de forma local) e fenilalanina amônia-liase (de forma sistêmica), indicando potencial efeito indutor de resistência nas plantas.

\section{LITERATURA CITADA}

AHUJA, I.; KISSEN, R.; BONES, A. M. et al. Phytoalexins in defense against pathogens. Trends in plant science, v.17, n.2, p.73-90, 2012.

\section{AZEVEDO, L. A. S. Manual de quantificação de doenças de plantas. São Paulo.1997.}

BARROS, F. C.; SAGATA, É.; FERREIRA, L. C. C. et al. Indução de resistência em plantas contra fitopatógenos. Bioscience Journal, v. 26, n. 2, p. 231-239, 2010.

BARROSO, G. M. Família Solanaceae Wettstein. In. Sistemática de angiospermas de Brasil. São Paulo. 1991. p. 62-74.

BIANCHINI, A.; MARINGONI, A. C.; CARNEIRO, S. M. P. G. et al. Doenças do feijoeiro. In KIMATI et al., Manual de fitopatologia: doenças das plantas cultivadas. $4^{\mathrm{a}}$ ed. São Paulo: Ceres, p.333-351, 2005.

BRAND, S.C.; BLUME, E.; MUNIZ, M.F.B. et al. Extratos de alho e alecrim na indução de faseolina em feijoeiro e fungitoxicidade sobre Colletotrichum lindemuthianum. Ciência

Rural, v.40, n.9, p.1881-1887, 2010.

CAMPOS, Â. D.; FERREIRA, A. G.; HAMPE, M. M. V. et al. Atividade de peroxidase e polifenoloxidase na resistência do feijão à antracnose. Pesquisa Agropecuária Brasileira, v. 39, n. 7, p. 637-643, 2004.

DAYAN, F. E.; CANTRELL, C. L.; DUKE, S. O. Natural products in crop protection.

Bioorganic \& Medicinal Chemistry, v.17, n.12, p.4022-4034, 2009.

DE LEÓN, M.A., SÁENZ, A.; JASSO-CANTU, D. et al. Fermented Flourensia cernua extracts and their in vitro assay against Penicillium expansum and Fusarium oxysporum. Food Technology and Biotechnology, v.51, p.233-239, 2013. 
DIAZ, C. G. Avaliação de danos causados por Xanthomonas axonopodis pv. phaseoli em feijoeiro (Phaseolus vulgaris L.) 2000. 79p. (Tese de Doutorado) - Piracicaba. Universidade de São Paulo, ESALQ, 2000.

DIDWANIA, N.; SADANA, D.; TRIVEDI, P. C. Antibacterial activity of a few medicinal plants against Xanthomonas campestris pv . campestris. International Journal Research in Pharmaceutical Sciences, v.4, n.2, p.177-182, 2013.

DIXON, R. A.; DEY, P. M.; LAWTON, M. A. et al. Phytoalexin indution in french bean: intercellular transmission of elicitation in cell suspension cultures and hypocotyl sections of Phaseolus vulgaris. Plant Physiology, v.71, n.2, p.251-256, 1983.

DUANGMAL, K.; APENTEN, R. K. O. A comparative estudy of poliphenoloxidases from taro (Colocasia esculenta) and potato (Solanum tuberosum var. romano). Food Chemistry, v.64, p.351-359, 1999.

FRANZENER, G.; SCHWAN-ESTRADA, K. R. F.; MOURA, G. S. et al. Induction of defense enzymes and control of anthracnose in cucumber by Corymbia citriodora aqueous extract. Summa Phytopathologica, v.44, n.1, p.10-16, 2018.

HUSSAIN, A.; BOSE, S.; WANG, J.-H. et al. Fermentation, a feasible strategy for enhancing bioactivity of herbal medicines. Food Research Internacional, v.81, p.1-16, 2016.

KOTAN, R.; DADASOĐLU, F.; KARAGOZ, K. et al. Antibacterial activity of the essential oil and extracts of Satureja hortensis against plant pathogenic bacteria and their potential use as seed disinfectants. Scientia Horticulturae, v.153, p.34-41, 2013.

KUHN, O.J.; PORTZ, R.L.; STANGARLIN, J.R. et al. Efeito do extrato aquoso de cúrcuma (Curcuma longa) em Xanthomonas axonopodis pv. manihotis. Semina: Ciências Agrárias, v.27, n.1, p.13-20, 2006.
MDEE, L. K.; MASOKO, P.; ELOFF, J. N. The activity of extracts of seven common invasive plant species on fungal phytopathogens. South African Journal of Botany, v.75, n.2, p.375-379, 2009.

MOURA, G. S.; FRANZENER, G.; STANGARLIN, J. R. et al. Atividade antimicrobiana e indutora de fitoalexinas do hidrolato de carqueja [Baccharis trimera (Less.) DC.]. Revista Brasileira de Plantas Medicinais, v. 16, n. 2, p. 309-315, 2014.

SILVA, E. G.; MOURA, A. B.; DEUNER, C. C. et al. Estudo de mecanismos de biocontrole do crestamento bacteriano do feijoeiro por bactérias. Revista Ceres, v.55, n.5, p.377-383, 2008.

SILVA, F. A. S.; AZEVEDO, C. A. V. Versão do programa computacional Assistat para o sistema operacional Windows. Revista Brasileira de Produtos Agroindustriais, v.4, n.1, p.71-78, 2002.

UMESHA, S. Phenylalanine ammonia-lyase activity in tomato seedlingsand its relations chipto bacterial cankered sease resistence. Phytoparasitica, v.34, n.1, p.68-71, 2006.

VIDHYASEKARAM, P. et al. Induction of systemic resistence by Pseudomonas fluorenscens Pf1 against Xanthomonas oryzae in rice leaves. Phytoparasitica, v.29, p.155-167, 2001.

VIECELLI, C.A.; MOERSCHBÄCHER, T. Controle do crestamento bacteriano comum na cultura do feijoeiro pelo uso de fertilizantes foliares.

Scientia Agraria Paranaensis, v.12, n.1, p.66-72, 2013.

VIGO, S.C.; MARINGONI, A.C.; CAMARA, R.C. et al. Ação de tinturas e óleos essenciais de plantas medicinais sobre o crestamento bacteriano comum do feijoeiro e na produção de proteínas de indução de resistência. Summa

Phytopathologica, v.35, n.4, p.293-304, 2009.

Recebido para publicação em 21/7/2018 e aprovado em 27/9/2018. 